\section{A feasibility study of cell phone and landline phone interviews for monitoring of risk and protection factors for chronic diseases in Brazil}

\author{
Exequibilidade do uso de entrevistas por telefone \\ celular e por telefone fixo no monitoramento \\ de fatores de risco e proteção para \\ doenças crônicas
}

\author{
Erly Catarina Moura 1,2 \\ Rafael Moreira Claro 2 \\ Regina Bernal 2 \\ Juliano Ribeiro 3 \\ Deborah Carvalho Malta 1,4 \\ Otaliba Morais Neto 1
}

\section{Introduction}

1 Ministério da Saúde, Brasília, Brasil.

2 Núcleo de Pesquisas Epidemiológicas em Nutrição e Saúde, Universidade de São Paulo, São Paulo, Brasil. 3 Expertise Pesquisas, Belo Horizonte, Brasil. 4 Escola de Enfermagem, Universidade Federal de Minas Gerais, Belo Horizonte, Brasil.

Correspondence E. C. Moura Ministério da Saúde. SQSW, Brasília, DF 70673-506, Brasil. erlycm@usp.br

\begin{abstract}
The study objective was to evaluate the feasibility of interviews by cell phone as a complement to interviews by landline to estimate risk and protection factors for chronic non-communicable diseases. Adult cell phone users were evaluated by random digit dialing. Questions asked were: age, sex, education, race, marital status, ownership of landline and cell phones, health condition, weight and height, medical diagnosis of hypertension and diabetes, physical activity, diet, binge drinking and smoking. The estimates were calculated using post-stratification weights. The cell phone interview system showed a reduced capacity to reach elderly and low educated populations. The estimates of the risk and protection factors for chronic non-communicable diseases in cell phone interviews were equal to the estimates obtained by landline phone. Eligibility, success and refusal rates using the cell phone system were lower than those of the landline system, but loss and cost were much higher, suggesting it is unsatisfactory as a complementary method in such a context.
\end{abstract}

Chronic Disease; Interview; Telephone
The current demographic situation in Brazil indicates an increase in life expectancy in all country regions and, consequently, an increase in the elderly population. This situation, along with improvements in sanitation, has led to a growth in morbid-mortality caused by chronic non-communicable diseases 1 . Nowadays, in Brazil, about $60 \%$ of total deaths and $40 \%$ of all diseases are caused by chronic non-communicable diseases 2 .

Chronic non-communicable diseases are characterized by presenting multiple and common risk factors, such as smoking, overweight, binge drinking, sedentarylifestyle andinadequate diet 3 . Many of these factors may be changed by public policies aiming to improve a population's quality of life, in order to reduce the prevalence of these diseases. For this reason, in 2006 the Brazilian Ministry of Health introduced, in all Brazilian state capitals and in the Federal District, the Risk and Protective Factors Surveillance System for Chronic Non-Communicable Diseases through Telephone Interviews (VIGITEL) 4.

Even though the data obtained has served as the baseline to establish the monitoring process, these values do not fully represent the adult population, since the study population from the system consists of adults living in households served by landline telephones. Data from the Brazilian Institute of Geography and Statistics (IBGE) in 2002/2003 showed that only six of the 
27 places studied presented coverage over $70 \%$, with this being one of the most important biases of VIGITEL 5 . These biases can be corrected, partially by the use of post-stratification weights, even though in the Federation units with coverage rates above $70 \%$ these bias is disregarded 6 . In general, VIGITEL underestimates the percentage of men, young people and those with lower levels of schooling 5,6,7,8,9. On the other hand, the growth of cell phone coverage 10, mainly in the pre-paid modality has drastically increased in Brazil, representing an important complement to landline coverage, aimed at reaching under-represented populations in VIGITEL and correcting possible remaining biases even after the use of post-stratification weights.

This study subsequently aims to evaluate the feasibility of the use of cell phone interviews (hereafter called VIGITEL-cell) as a complement to VIGITEL, which operates only with land phones (hereafter called VIGITEL-landline) by determining the differences between cell phone interviews and the interviews performed by VIGITEL-landline regarding the socio-demographic characteristics of the interviewed population, the estimates of certain risk and protection factors for chronic non-communicable diseases as well as the performance of the system.

\section{Material and methods}

\section{Study population and sampling}

Adult ( $\geq 18$ years old) cell phone users were studied in two State Capitals served by a VIGITELlandline: Belo Horizonte (in Minas Gerais State) and Maceió (Alagoas). These cities were chosen because they have landline coverage in extreme limits - slightly above $70 \%$ in Belo Horizonte and almost $40 \%$ in Maceió.

The method used to choose the sample for mobile lines consisted in random digit dialing 11 . This procedure of choosing samples of mobile lines for each conglomerate occurs in two steps, the primary sampling unit (PSU) being defined by the first four digits. The phone directory to the PSU lot was obtained at the National Agency of Telecommunications. In the first step, 1,000 PSUs were randomly chosen. In each PSU selected, three phone numbers were generated by randomly adding the four last suffixes which ranged from 0000 to 9999. Each one of these numbers were dialed allowing to classify its PSU either as "promising" or "not promising". When all the dialed numbers were classified as not promising, that PUS was discarded, otherwise it was retained. The process was then repeated until all PSUs were used. In the second step, in each retained PSU, 20 phone numbers were generated by randomly adding the four last suffixes. These phone numbers, from which the interviews were conducted, were dialed until those potentially selected were all used.

\section{Data collection}

All evaluated individuals were questioned about: age, sex, schooling, race, marital status, land and cell phone possession, health conditions, weight and height, hypertension and diabetes medical diagnosis. VIGITEL-cell was operated at the same time as VIGITEL-landline by interviewers skilled at landline interviews. The first calls for all the selected lines aimed at identifying the line and the respondent's eligibility for the study. As the interview was conducted through a cell phone, the first thing to be evaluated was the phone call answering availability. Afterwards, the city of residence and age of the attendant were confirmed. Then, the study eligible population was randomly divided into three groups, to answer a certain module of questions from the VIGITEL-landline questionnaire: physical activity standard $(\mathrm{n}=440)$, diet standard $(\mathrm{n}=384)$ and binge drink and smoking standard $(n=383)$. On average, each interview lasted 5 minutes and 17 seconds.

Whenever the answerer agreed, the interview was carried out immediately, otherwise it was scheduled for another day and hour that was more convenient for the respondent. Up to ten phone calls were made to every phone number, obligatorily in the morning, in the afternoon and in the evening on a working day, in the morning and in the afternoon on Saturday and in the afternoon on Sunday or on a holiday.

\section{Data analysis}

The VIGITEL-cell evaluation initially served to focus the sample representation under study within the system, taking into account the extent to which the sample represents the set of adult individuals from each city. For this purpose, an evaluation was carried out of the existing sociodemographic differences between those individuals that answered the interview by cell phone, those by landline phone and the total adult population given in the 2000 Demographic Census (IBGE. http://www.ibge.gov.br).

Confidence intervals of $95 \%(95 \% \mathrm{CI})$ were calculated for the estimates of prevalence of selected indicators, for adult city population with cell phone and for city total adult population. To correct possible election and covering biases, 
weights were introduced. In the case of the population with cell phone, the estimates were produced using corresponding individual weights based on the ratio between the number of adults who use the cellular called and the number of cell phone lines used by the person interviewed. In the case of total population, individual weights were multiplied by post-stratification weights that take into account the existing socio-demographic differences between the adult population with a cell phone and the total adult population of the city. To obtain post-stratification weights, the population sample with cell phone was compared to a sample of the city population from the Demographic Census. Such a comparison was made based on a stratification of the two samples by sex (masculine and feminine), six age groups (18-24, 25-34, 35-44, 45-54, 55-64 and $\geq 65$ years) and three schooling levels (0-8, 9-11 and $\geq$ 12 years). For each stratum, the frequency ratio between census sample and monitoring system sample was calculated, in order to correct eventual sub or super-representation of each stratum studied by the monitoring system 12 . Weights of post-stratification were calculated separately for each module of answers, as populations were different from each other. Additionally, differences between cell and landline were also investigated for all indicators.

Indicators referring to system technical performance - eligibility rates (lines of potential use/total lines carried out), refusal rates (refusals/eligible lines), success rates (concluded interviews/eligible lines) and loss rates [lines of potential use (concluded interviews + refusals) / eligible lines)] and interview costs (call price + call attempts to complete an interview) - were also evaluated. Office phone numbers, non existing numbers and users under the age of 18 or residents in a different city to that being evaluated were considered ineligible, being discarded on the first call; off service phone numbers, disconnected phone numbers, out of service area/ coverage, those programmed not to receive calls, those temporarily programmed not to receive calls, those programmed not to receive collect calls or in which it was not possible to complete the call were discarded after 10 calls with the same outcome. Every other situation (completed interview, interrupted interview, scheduled interview, personalized answering machine, message in-box, busy, not answered calls and refusal) were considered eligible.

Data was analyzed with the Stata software (Stata Corp., College Station, USA), and the results were compared with a VIGITEL-landline 8 by means of a $95 \% \mathrm{CI}$.

\section{Ethical aspects}

In this study, as interviews were conducted by phone, free and clarified consent was replaced by verbal consent obtained by phone during contact with people interviewed. The study was approved by the Health Commission for Research Ethics with Human Beings in the Brazilian Ministry of Health.

\section{Results}

We performed 1,207 interviews through calls made to cellular telephones; 566 in Belo Horizonte and 641 in Maceió. The performance evaluation of the VIGITEL-cell was compared with data for the VIGITEL-landline, made in 2008 in the same cities, in a total of 2.016 interviews in each one ${ }^{8}$.

Figures 1 and 2 show that the sex distribution of the population interviewed by cell phone is more similar to the total adult population than was the case for the population interviewed by landline phone, where men are under-represented. The distribution by age range of individuals interviewed by cell is close to that of the total adult population, even if there is an overestimation in the proportion of people aged between 25 and 34 and an underestimation of those over 45 . For both those populations interviewed by cell and those by landline phones the proportion of individuals with low levels of schooling was underestimated. In general, the two cities present similar results, though in Maceió the frequency of individuals with up to 8 years of schooling is higher for the population interviewed by cell compared with the landline group.

All people interviewed were questioned on health, morbidity and nutritional status; however 92 did not divulge information about weight and/ or height, reducing to 1,115 the number of adults whose nutritional status was evaluated.

The estimates of risk and protection factors for chronic non-communicable diseases in interviews by cell phone were compared with estimates obtained by VIGITEL-landline in 20088 (Tables 1 and 2). Considering only the sample design weight (the ratio between people who use the number that was called and the devices available to the person who was interviewed), there was found to be a minor frequency of hypertension and regular consumption of fruits and vegetables, a higher frequency of binge drinking and soft-drink consumption in those interviewed by cell phone in Belo Horizonte. In Maceió, hypertension was also lower, as well as diabetes, and the consumption of visible fatty meat was 
Estimates for the distribution (\% and $95 \% \mathrm{Cl}$ ) of the adult population with cell phone, of the adult population with land phone and of the total adult population according to socio-demographic variables. Belo Horizonte, Minas Gerais State, Brazil, 2008.

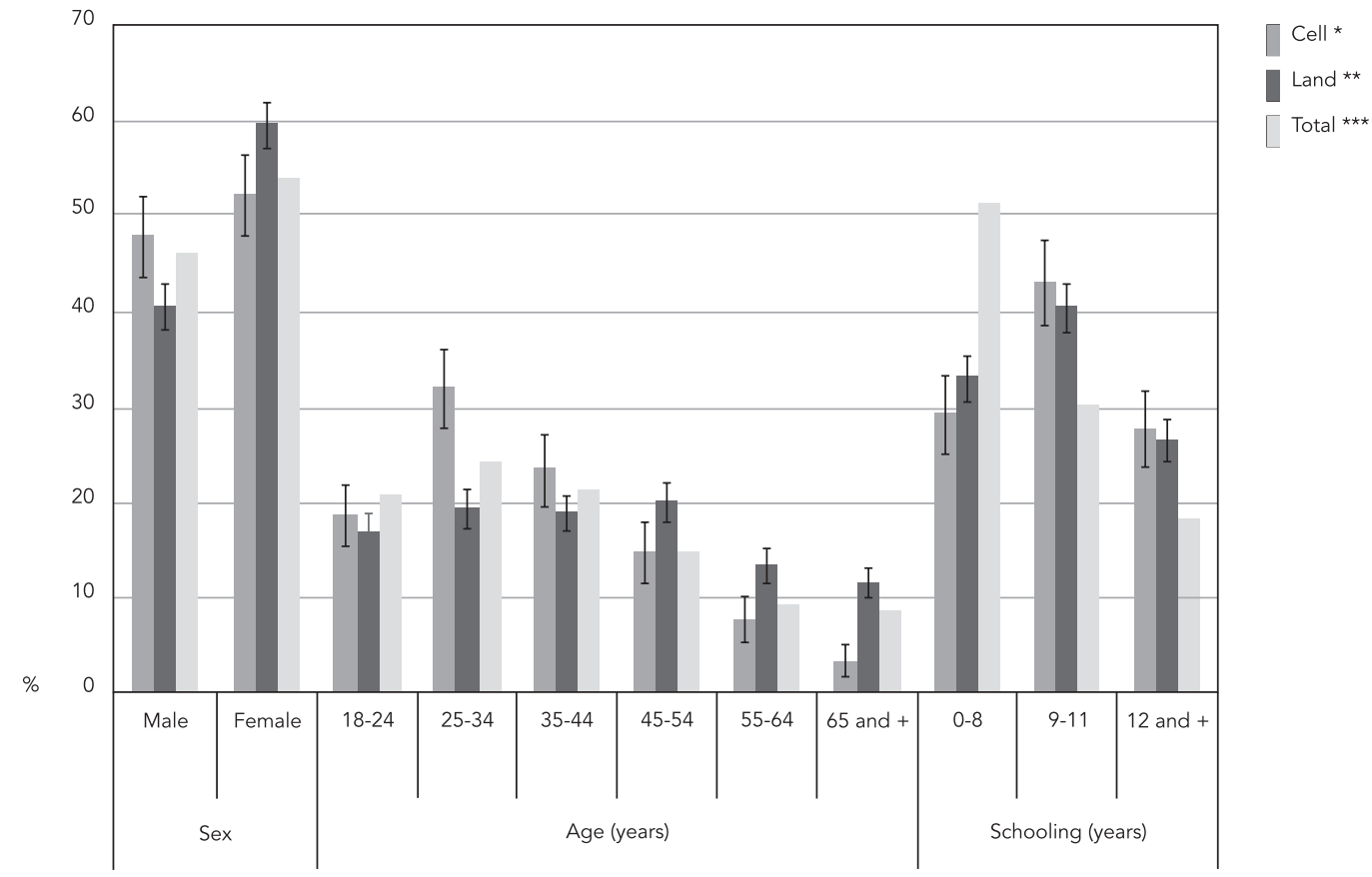

* Weighted to represent distribution of population aged $\geq 18$ years with cell phone;

** Weighted to represent distribution of population aged $\geq 18$ years with landline phone;

*** Weighted to represent distribution of population aged $\geq 18$ years according to Brazil's Demographic Census for the year 2000 (http://www.ibge.gov.br).

higher among those interviewed by cell phone. After the use of the post-stratification weights, the estimates were found to be similar between the interviews by cell and landline phone, even when the differences between cell and landline indicators were examined.

Figure 3 illustrates system performance. Rates of eligibility, success and refusals of cell were found to be lower than for those responding through the landline system; however its loss rate is considerably higher. These factors, allied to the higher cost of the cell phone call, have comparatively increased the cost of cell interviews by a factor of 6.6 compared with landlines.

\section{Discussion}

The use of interviews by cell phone, as opposed to by landline phone, increased the participation of two groups: men, guaranteeing a similar distri- bution ratio for sexes in individuals between 25 and 35 years old (reducing the ratio of people $\geq$ 45 years); and individuals with a greater number of years of schooling ( $\geq 9$ years of study), underestimating the ratio of those with low levels of schooling (0-8 years) as in landline interviews. With the exception of the more elderly, the frequency of age and schooling stratum in cell phone interviews had a similar distribution to those obtained in landline interviews.

A similar situation with regard to a greater participation of men and young people was observed in a study conducted in three American states 13 . This increase can be explained by the improved access to these demographic strata outside of their homes. It is natural to believe that a similar phenomenon also serves as an explanation for the results of the present study.

In Brazil, $67.3 \%$ of the people interviewed in Belo Horizonte and $84.6 \%$ in Maceió use prepaid cell phones. This may explain the increased 
Estimates for the distribution (\% and $95 \% \mathrm{Cl}$ ) of the adult population with cell phone, of the adult population with land phone and of the total adult population according to socio-demographic variables. Maceió, Alagoas State, Brazil, 2008.

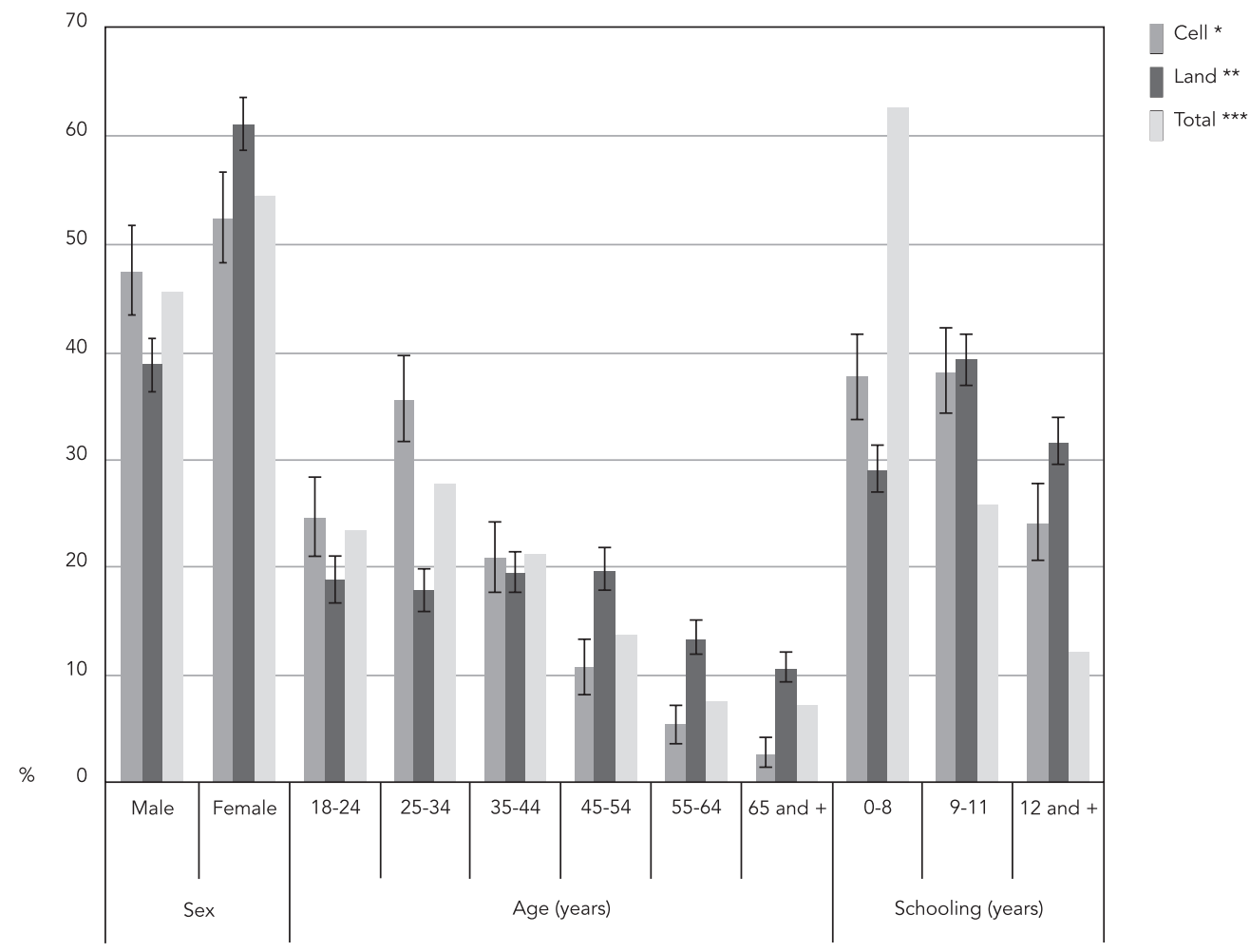

* Weighted to represent distribution of population aged $\geq 18$ years with cell phone;

** Weighted to represent distribution of population aged $\geq 18$ years with landline phone;

*** Weighted to represent distribution of population aged $\geq 18$ years according to Brazil's Demographic Census for the year 2000 (http://www.ibge.gov.br).

participation of those from a lower education stratum, as this modality demands lower financial investment and allows for greater control of amounts spent in bills, compared with post-paid cell phones or landlines. On the other hand, the use of cell phones, recently introduced in Brazil, has not been able to reach the elderly population (compared with young people).

The estimates comparison from some of the indicators evaluated show that people interviewed by cell phone and landline phone behave differently 14 . This study confirmed that among cell phone users there is a higher frequency of smokers, binge drinking and people that are physically active during leisure time, with good health conditions and a lower prevalence of diabetes. Our data also shows there to be some differences between some indicators: a lower frequency of hypertension in both cities evaluated, a lower frequency of diabetes in Maceió, lesser regular fruit and vegetable consumption in Belo Horizonte, a higher frequency of consumption of visible meat fat in Maceió, a higher frequency of binge drinkers and soft-drink consumers in Belo Horizonte. Apart from the age range differences between cell phone and landline phone users, which leads to a greater frequency of conditions more typical among elderly people (hypertension and diabetes, for example) and protection (nutrition) and/ or lowering of risk factor (binge drinking and soft drinks) behaviors, regional dissimilarities also explain some differences between the cities evaluated, since one is located in the southeastern central region (Belo Horizonte) and the other in the northeast coastal region (Maceió). However, the differences found in the estimates between 
Percentage $(\%$ and $95 \% \mathrm{Cl})$ of risk and protection factors for chronic non-communicable diseases according to type of telephone interview. Surveillance System of Risk and Protective Factors for Chronic Non-Communicable Diseases through Telephone Interviews (VIGITEL). Belo Horizonte, Minas Gerais State, Brazil, 2008.

\begin{tabular}{|c|c|c|c|c|c|}
\hline \multirow[t]{4}{*}{ Risk and protection factors } & \multicolumn{5}{|c|}{ Interview } \\
\hline & \multicolumn{2}{|c|}{ Cell phone } & \multicolumn{2}{|c|}{ Landline phone } & \multirow{2}{*}{$\begin{array}{c}\text { Difference } \\
\text { between cell and } \\
\text { landline ** }\end{array}$} \\
\hline & Weight 1 * & Weight $2 * \star$ & Weight 1 * & Weight $2 \star \star$ & \\
\hline & $\%(95 \% \mathrm{Cl})$ & $\%(95 \% \mathrm{Cl})$ & $\%(95 \% \mathrm{Cl})$ & $\%(95 \% \mathrm{Cl})$ & $\%(95 \% \mathrm{Cl})$ \\
\hline Poor self-related health & $3.0(1.5-4.4)$ & $3.8(1.8-5.8)$ & $3.9(2.9-4.8)$ & $3.5(2.5-4.4)$ & $0.3(-1.9-2.5)$ \\
\hline Hypertension & $17.6(14.4-20.9)$ & $21.9(17.2-26.5)$ & $27.6(25.4-29.8)$ & $24.5(22.0-27.0)$ & $-2.6(-7.9-2.6)$ \\
\hline Diabetes & $4.0(2.3-5.6)$ & $5.8(2.9-8.8)$ & $6.0(4.7-7.0)$ & $5.0(3.9-6.1)$ & $0.8(-2.3-4.0)$ \\
\hline Overweight & $39.6(35.3-44.0)$ & $43.6(38.0-49.2)$ & $42.8(40.3-45.3)$ & $43.3(39.5-47.2)$ & $0.2(-6.5-4.1)$ \\
\hline Obesity & $10.4(7.7-13.1)$ & $11.9(8.3-15.5)$ & $11.4(9.8-12.9)$ & $12.1(9.8-14.3)$ & $-0.2(-4.4-4.1)$ \\
\hline Binge drinking & $28.1(21.2-35.0)$ & $25.1(17.1-33.1)$ & $20.2(18.2-22.1)$ & $20.8(18.2-23.5)$ & $4.3(-4.2-12.7)$ \\
\hline Sufficient leisure-time physical activity & $16.6(11.2-22.0)$ & $21.3(12.2-30.5)$ & $16.3(14.5-18.0)$ & $16.1(13.7-18.4)$ & $5.3(-4.2-14.7)$ \\
\hline Regular fruit and vegetable intake & $32.5(25.3-40.0)$ & $35.2(24.5-45.9)$ & $44.0(41.6-46.4)$ & $38.6(35.3-42.0)$ & $-3.4(-14.6-7.7)$ \\
\hline Recommended fruit and vegetable intake & $21.4(15.1-27.7)$ & $26.6(15.6-37.6)$ & $25.0(22.9-27.1)$ & $21.6(19.0-24.2)$ & $5.0(-6.2-16.2)$ \\
\hline Visible meat fat intake & $44.0(36.4-51.6)$ & $42.7(32.7-52.7)$ & $36.3(34.0-38.7)$ & $41.1(37.4-44.8)$ & $1.6(-9.1-12.2)$ \\
\hline Whole milk intake & $58.6(51.1-66.1)$ & $61.0(51.6-70.4)$ & $53.7(51.3-56.1)$ & $54.4(50.6-58.1)$ & $6.7(-3.4-16.8)$ \\
\hline Regular soft-drink intake & $31.6(24.4-38.7)$ & $26.8(19.0-34.6)$ & $22.1(20.1-24.1)$ & $27.1(23.2-30.9)$ & $-0.2(-8.9-8.4)$ \\
\hline Smoker & $18.7(12.8-24.6)$ & $15.9(9.8-21.9)$ & $15.1(13.4-16.8)$ & $19.2(15.4-23.0)$ & $-3.3(-10.4-3.8)$ \\
\hline Ex-smoker & $20.7(14.6-26.9)$ & $26.1(16.4-35.9)$ & $22.1(20.2-24.1)$ & $20.2(17.9-22.5)$ & $5.9(-4.1-16.0)$ \\
\hline Smoker of 20 or more cigarettes/day & $7.3(3.3-11.3)$ & $6.7(2.4-10.9)$ & $5.4(4.3-6.5)$ & $7.9(4.4-11.5)$ & $-1.3(-6.8-4.3)$ \\
\hline
\end{tabular}

* Weighted to represent distribution of population aged $\geq 18$ years with cell or landline phone;

** Weighted to represent distribution of population aged $\geq 18$ years according to Brazil's Demographic Census for the year 2000 (http://www.ibge.gov.br).

cell phone and landline phone respondents disappear after post-stratification weights are used, so that populations interviewed by cell phone and landline phone show similar frequencies of the indicators studied (physical activity, smoking, diet, morbidity and health condition evaluation). This way, for the total population, as far as the studied factors are concerned there were no differences between the two sub-samples (people interviewed by landline phone and cell phone) in Maceió and Belo Horizonte.

As to the system performance, even though it is not yet possible to make direct comparisons between data from Brazil and that of other studies $13,15,16$, it is worth pointing out the low eligibility of numbers called and the higher interview cost per cell phone. The interview cost per cell phone in Brazil was 6.6 times higher than the interview cost per landline phone, a much higher cost than that found in the United States - 2.4 times (including financial incentives for the people interviewed) - capable of reaching five times this value, depending on the sampling system 16 .
Both the growth of surveys performed by residential landline telephone and the recent increase in coverage of cell telephony (and a fall in landline phone coverage) have been addressed by many researchers, particularly in the United States. Data from a national survey in the United States 14 shows that in 2008, 20.2\% of households owned only cell phones, which in general is not taken into account when it comes to selecting the sample to be evaluated. Although it is recognized that the differences between people with cell phones and those with landline phones may cause a coverage bias, there is unanimity in the view that the introduction of cell phones will not solve the problem, since part of the population does not own any kind of telephone. The use of post-stratification weights, such as those used in the VIGITEL, is widely recommended to reduce this bias 16 , not only for studies in the health area, but also in other areas, such as the recent example of the North American presidential election 14 .

In conclusion, the cell phone interviewing system was found to be unsatisfactory regarding 
Percentage $(\%$ and $95 \% \mathrm{Cl})$ of risk and protection factors for chronic non-communicable diseases according to type of telephone interview. Surveillance System of Risk and Protective Factors for Chronic Non-Communicable Diseases through Telephone Interviews (VIGITEL). Macéio, Alagoas State, Brazil, 2008.

\begin{tabular}{|c|c|c|c|c|c|}
\hline \multirow[t]{4}{*}{ Risk and protection factors } & \multicolumn{5}{|c|}{ Interview } \\
\hline & \multicolumn{2}{|c|}{ Cell phone } & \multicolumn{2}{|c|}{ Landline phone } & \multirow{2}{*}{$\begin{array}{c}\text { Difference } \\
\text { between cell and } \\
\text { landline ** }\end{array}$} \\
\hline & Weight 1 * & Weight $2 * \star$ & Weight 1 * & Weight 2 ** & \\
\hline & $\%(95 \% \mathrm{Cl})$ & $\%(95 \% \mathrm{Cl})$ & $\%(95 \% \mathrm{Cl})$ & $\%(95 \% \mathrm{Cl})$ & $\%(95 \% \mathrm{Cl})$ \\
\hline Poor self-related health & $4.8(3.0-6.5)$ & $5.6(3.2-8.0)$ & $5.6(4.4-6.7)$ & $6.7(4.5-8.9)$ & $-1.1(-4.4-2.2)$ \\
\hline Hypertension & $17.4(14.3-20.5)$ & $20.2(15.8-24.7)$ & $25.0(22.9-27.1)$ & $21.8(18.6-25.0)$ & $-1.6(-7.0-3.9)$ \\
\hline Diabetes & $3.5(2.0-5.0)$ & $7.1(2.4-11.8)$ & $6.6(5.3-7.8)$ & $4.9(3.7-6.1)$ & $2.2(-2.7-7.0)$ \\
\hline Overweight & $41.0(36.8-45.3)$ & $46.7(41.1-52.4)$ & $43.8(41.3-46.4)$ & $42.5(38.2-46.8)$ & $4.3(-2.9-11.4)$ \\
\hline Obesity & $13.1(10.2-16.0)$ & $16.0(11.8-20.1)$ & $13.1(11.4-14.9)$ & $13.9(10.9-16.9)$ & $2.0(-3.1-7.2)$ \\
\hline Binge drinking & $23.8(17.4-30.2)$ & $24.2(16.2-32.3)$ & $16.9(15.0-18.7)$ & $16.2(13.2-19.1)$ & $8.1(-0.4-16.6)$ \\
\hline Sufficient leisure-time physical activity & $15.2(10.4-20.1)$ & $12.1(7.5-16.7)$ & $18.4(16.5-20.3)$ & $15.6(12.6-18.6)$ & $-3.4(-8.9-2.0)$ \\
\hline Regular fruit and vegetable intake & $29.7(23.1-36.5)$ & $31.5(22.7-40.3)$ & $37.3(35.0-39.6)$ & $28.5(25.1-31.9)$ & $3.0(-6.4-12.4)$ \\
\hline Recommended fruit and vegetable intake & $15.3(10.0-20.6)$ & $16.1(9.1-23.1)$ & $19.8(17.9-21.7)$ & $14.5(12.1-17.0)$ & $1.6(-5.9-9.0)$ \\
\hline Visible meat fat intake & $37.1(30.1-44.1)$ & $36.9(27.8-45.9)$ & $27.0(24.8-29.1)$ & $29.1(25.4-32.8)$ & $7.7(-2.0-17.5)$ \\
\hline Whole milk intake & $47.0(39.7-54.3)$ & $43.0(33.1-53.0)$ & $48.7(46.3-51.1)$ & $49.7(45.5-54.0)$ & $-6.7(-17.5-4.2)$ \\
\hline Regular soft-drink intake & $18.1(12.5-23.6)$ & $15.7(9.4-22.1)$ & $13.0(11.3-14.7)$ & $15.2(12.0-18.3)$ & $0.6(-6.5-7.6)$ \\
\hline Smoker & $11.1(6.4-15.8)$ & $11.2(5.5-17.0)$ & $9.3(7.9-10.7)$ & $9.7(7.4-12.0)$ & $1.5(-4.6-7.7)$ \\
\hline Ex-smoker & $19.0(13.1-24.9)$ & $18.9(12.2-25.6)$ & $21.7(19.8-23.7)$ & $21.6(18.3-24.9)$ & $-2.7(-10.2-4.8)$ \\
\hline Smoker of 20 or more cigarettes/day & $2.5(2.3-4.8)$ & $2.1(1.4-4.2)$ & $5.4(4.3-6.5)$ & $2.8(1.3-4.2)$ & $-0.6(-3.1-2.0)$ \\
\hline
\end{tabular}

* Weighted to represent distribution of population aged $\geq 18$ years with cell or landline phone;

** Weighted to represent distribution of population aged $\geq 18$ years according to Brazil's Demographic Census for the year 2000 (http://www.ibge.gov.br).

its technical performance, having a high cost, still presenting very low coverage as regards the total adult population especially as far as elderly people and low education individuals are concerned. In addition to this, a careful approach must be taken 17 , since the cell phone user's legal situation may not allow him/her to answer the telephone. The estimates (corrected by poststratification weights) of the risk and protection factors were similar between both the cell phone system and landline phone system and there were no benefits in using the cell system in the conditions mentioned. It is recommend that the evaluation of landline telephony and mobile coverage growth be expanded across the country and that similar studies be carried out over the next years, in order to monitor behavior changes and the rise of new factors that justify the introduction of a cellular phone subsample in the future, since in the city with low landline coverage (Maceió) the participation of people with low education levels in interviews by cell phone was higher. This difference may result from low landline coverage and/or due to demographic and socio-economic differences, that may interfere with behavior regarding risk and protection factors for chronic non-communicable diseases. 
Performance of the cell phone and landline phone interview system. Belo Horizonte (Minas Gerais State) and Maceió (Alagoas State), Brazil, 2008.

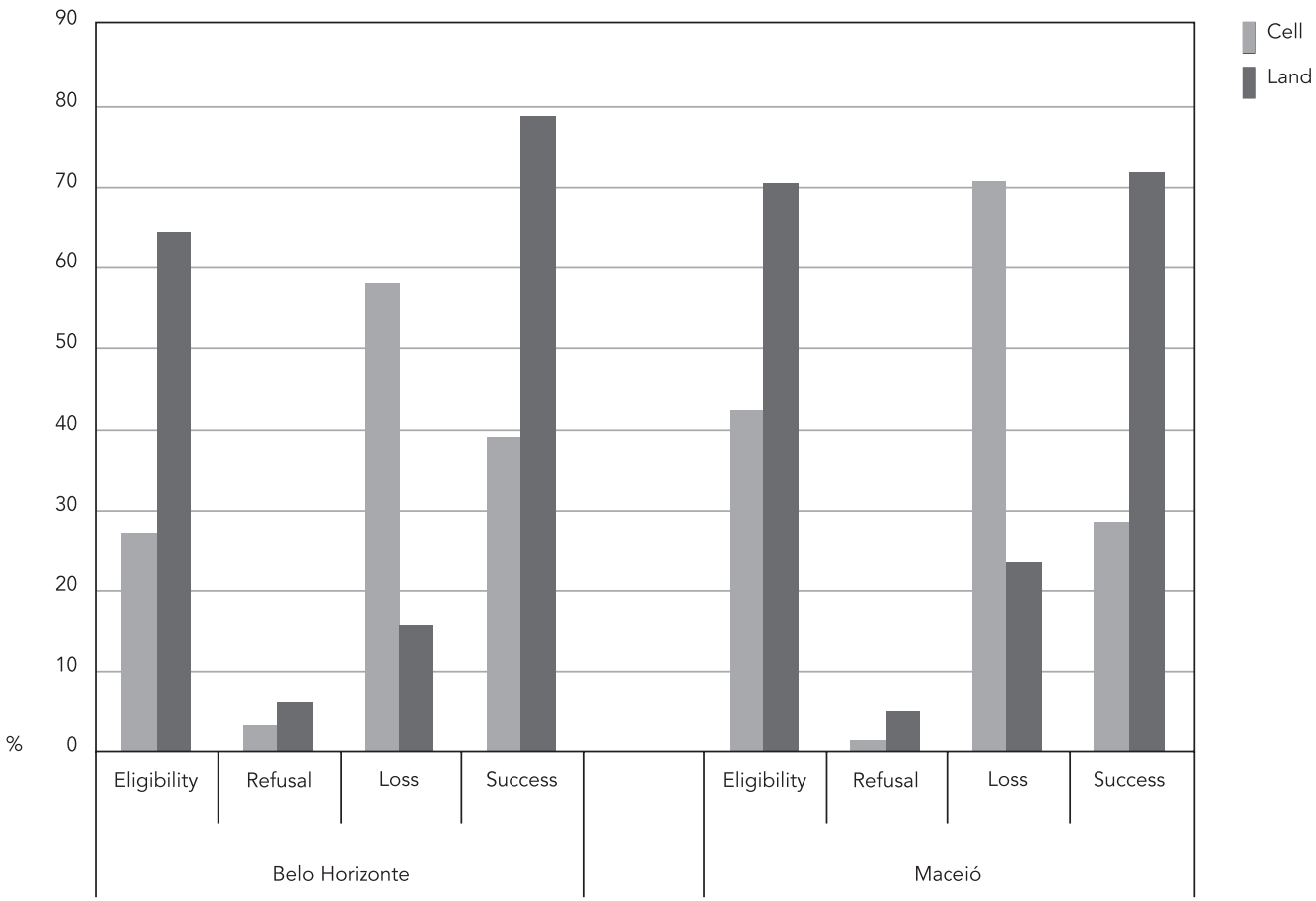

\section{Resumo}

Avaliar a exequibilidade do uso de entrevistas por telefone celular de forma complementar ao fixo para estimativas de fatores de risco e proteção para doenças crônicas não transmissiveis. Questionou-se: idade, sexo, escolaridade, cor, situação conjugal, posse de telefones fixos e celulares, estado de saúde, peso e altura, diagnóstico hipertensão arterial e diabetes, atividade física, alimentação, consumo de bebidas alcoólicas e tabagismo. As estimativas foram calculadas com peso pós-estratificação. Observou-se, na população entrevistada pelo celular, superestimação na idade entre 25 e 34 anos e subestimação na idade $\geq 45$ anos e na faixa de baixa escolaridade. No que se refere aos fatores de risco e proteção para doenças crônicas, as estimativas obtidas nas entrevistas por telefone celular foram iguais às obtidas pelo telefone fixo. As taxas de elegibilidade, de sucesso e de recusas do sistema por telefone celular foram menores do que as do sistema por telefonia fixa; ademais, a perda e o custo foram muito maiores no primeiro sistema, sugerindo que este é insatisfatório como complemento no atual contexto.

Doença Crônica; Entrevista; Telefone 


\section{Contributors}

E. C. Moura and J. Ribeiro were responsible for data collection and analysis and for writing the article. R. M. Claro participated in the data analysis and article write-up. R. Bernal contributed towards the project design and data analysis. D. C. Malta and O. Morais Neto reviewed the article.

\section{References}

1. Ministério da Saúde. Saúde Brasil 2006: uma análise da situação de saúde no Brasil. Brasília: Ministério da Saúde; 2006.

2. Malta DC, Cezário AC, Moura L, Morais Neto OL, Silva Junior JB. A construção da vigilância e prevenção das doenças crônicas não transmissíveis no contexto do Sistema Único de Saúde. Epidemiol Serv Saúde 2006; 15:47-65.

3. World Health Organization. World Health Report 2002. Reducing risks, promoting healthy life. Geneva: World Health Organization; 2002.

4. Moura EC, Morais Neto OL, Malta DC, Moura L, Silva NN, Bernal R, et al. Vigilância de Fatores de Risco para Doenças Crônicas por Inquérito Telefônico nas capitais dos 26 estados brasileiros e no Distrito Federal (2006). Rev Bras Epidemiol 2008; 11 Suppl 1:20-37.

5. Secretaria de Vigilância em Saúde, Ministério da Saúde. VIGITEL Brasil 2006. Vigilância de fatores de risco e proteção para doenças crônicas por inquérito telefônico. Brasília: Ministério da Saúde; 2007.
6. Bernal R, Silva NN. Cobertura de linhas telefônicas residenciais e vícios potenciais em estudos epidemiológicos. Rev Saúde Pública 2009; 43:421-6.

7. Secretaria de Vigilância em Saúde, Ministério da Saúde. VIGITEL Brasil 2007. Vigilância de fatores de risco e proteção para doenças crônicas por inquérito telefônico. Brasília: Ministério da Saúde; 2008.

8. Secretaria de Vigilância em Saúde, Ministério da Saúde. VIGITEL Brasil 2008. Vigilância de fatores de risco e proteção para doenças crônicas por inquérito telefônico. Brasília: Ministério da Saúde; 2009.

9. Secretaria de Vigilância em Saúde, Ministério da Saúde. VIGITEL Brasil 2009. Vigilância de fatores de risco e proteção para doenças crônicas por inquérito telefônico. Brasília: Ministério da Saúde; 2010.

10. Instituto Brasileiro de Geografia e Estatística. Pesquisa Nacional por Amostra de Domicílios 2004: síntese dos indicadores. Rio de Janeiro: Instituto Brasileiro de Geografia e Estatística; 2005. 
11. Potthoff RF. Some generalizations of the MitofskyWaksberg technique for random digit dialing. J Am Stat Assoc 1987; 82:409-18.

12. Moura EC, Malta DC, Morais Neto OL, Monteiro CA. Prevalence and social distribution of risk factors for chronic non communicable diseases in Brazil. Rev Panam Salud Pública 2009; 26:17-22.

13. Link MW, Battaglia MP, Frankel MR, Osborn L, Mokdad A. A comparison of address-based sampling versus random-digit dialing for general population surveys. Public Opin Q 2008; 72:6-27.

14. Blumberg SJ, Luke JV. Wireless substitution: early release of estimates from the National Health Interview Survey, July-December 2008. http:// www.cdc.gov/nchs/data/nhis/earlyrelease/wire less200905.pdf (accessed on May/2009).
15. Brick JM, Dipko S, Presser, Tucker C, Yuan Y. Non response bias in a dual frame sample of cell and landline numbers. Public Opin Q 2006; 70:780-93.

16. Keeter S, Kenned C, Clark A, Tompson T, Mokrzycki M. What's missing from national landline RDD surveys? Public Opin Q 2007; 71:772-92.

17. Lavrakas PJ, Shuttles CD, Steeh C, Fienberg SH. The state of surveying cell phone numbers in the United States. Public Opin Q 2007; 71:840-54.

Submitted on 20/Mar/2010

Final version resubmitted on 03/Sep/2010 Approved on 21/Sep/2010 